\title{
Türkiye’de Eğitim ve Ekonomik Büyüme: Eşbütünleşme Yaklaşımı
}

\author{
Y1lmaz KÖPRÜCÜ*, Tufan SARITAŞ**
}

ÖZ

Büyüme alan yazınında, eğitim ve ekonomik büyüme konusu araştırmacılar tarafından yoğun ilgi görmektedir. 1980-2013 dönemini kapsayan bu çalıșma, Türkiye'ye ait yıllık verilerle eğitim ile ekonomik büyüme arasında olası uzun dönemli bir ilişkinin varlığını araştırma amacındadır. Bu amaç doğrultusunda kullanılan yöntemler ARDL ve Johansen yaklaşımlarıdır. Modele ait değişkenler: kişi başına düşen gelir, sermaye düzeyi, istihdam oranı ve eğitim düzeyidir. Gelir, sermaye ve istihdam oranının logaritma formu kullanılmıştır. ARDL ve Johansen yaklaşımı bulgularına göre değişkenler eşbütünleşiktir. ARDL yönteminin uzun dönem modeline göre sermaye, emek ve eğitim düzeyi değişkenleri istatistiksel olarak anlamlı ve ekonomik büyüme üzerinde de pozitif yönlü bir etkiye sahiptir. Kısa dönem modelinde ise sermaye değişkeni istatistiksel olarak anlamlı ve büyümeyi pozitif etkilemektedir. Uzun dönemli ilişkinin varlığını ifade eden eşbütünleşme yaklaşımından sonra Granger nedensellik analizini yapabilmek için TodaYamamoto yaklaşımı uygulanmıştır. "Eğitim düzeyi ekonomik büyümenin Granger nedenidir, ancak ekonomik büyüme eğitim düzeyinin Granger nedeni değildir” sonucuna ulaşılmıştır.

Anahtar Kelimeler: Eğitim, Ekonomik Büyüme, Eşbütünleşme, Granger Nedensellik, Türkiye

JEL Sınıflandırması: I25, O40, C22

\section{Education and Economic Growth in Turkey: Cointegration Approach}

\begin{abstract}
In the literature related to the field of economic growth, the issue of education and growth attract a great deal of attention by the researchers. This study, covering the period of 1980-2013, aims to explore the possible long-run relationship between economic growth and education by using the annual data pertaining to Turkey. The methods used in line with this objective are ARDL (Autoregressive Distributed Lag) and Johansen approaches. The variables of the model are GDP per capita, capital ratio, employment rate and level of education. The logarithm form of GDP per capita, capital ratio and employment rate were used. According to the findings of ARDL and Johansen approach, the variables are cointegrated. With respect to the long run model of ARDL approach, the variables of capital, employment and education level are statistically significant and have a positive effect on economic growth. In the short run model, on the other hand, the variable of capital is statistically significant and has a positive effect on growth. After the cointegration approach elucidating the existence of long-run relationship, Toda-Yamamoto approach was performed in order to be able to carry out Granger causality test. It was concluded that although education level is Granger cause of economic growth, economic growth is not Granger cause of education.
\end{abstract}

Keywords: Education, Economic Growth, Cointegration, Granger Causality, Turkey

JEL Classification: $I 25, O 40, C 22$

Geliş Tarihi / Received: 13.02.2017 Kabul Tarihi / Accepted: 27.03.2017

\footnotetext{
* Arş.Grv., Eskişehir Osmangazi Üniversitesi, İIBF, İktisat Bölümü, ykoprucu@ogu.edu.tr

** Doktora Öğrencisi, Bilecik Şeyh Edebali Üniversitesi, SBE, tufansaritas@gmail.com
} 


\section{GİRIŞ}

Büyüme teorisinde sermaye ve emek değişkenleri kadar ülkelerin eğitim düzeyini ifade eden değişkenler de önem taşımaktadır. Romer (1986) geliştirmiş olduğu içsel büyüme modellerini büyüme teorisine kazandırmıştır. Bilindiği üzere, içsel büyüme modellerine ait değişkenlerden birisi de beşeri sermayedir. Bu bağlamda Schultz (1961), beşeri sermayeyi eğitim ve sağlığın birleşimi olarak tanımlamaktadır. Okullaşma düzeyinin yanı sıra, firma düzeyinde düşünüldüğünde, çalışanlarının verimliliğini artırmak isteyen şirketler iş yerinde verilen eğitimlerin masraflarını karşılamaya gönüllüdür. Böylece firmalar açısından verimliliğin artacağı ve dolayısıyla çalışanlar için de kazanç artışı olacağı beklenir (Becker, 1975: 13-44). Okullaşma ile beşeri sermaye unsurunun niteliğinin artırılmasıyla kişilerin kazançlarında yaşanan artış, uzun dönemde gelir eşitsizliğini de beraberinde getirmektedir (Mincer, 1974: 8396). Bu çerçevede, çalışmadaki amacımız Türkiye'de eğitimin ekonomik büyüme üzerindeki olası etkisini açıklamaya çalışmaktır. Bu amaç doğrultusunda ARDL ve Johansen yaklaşımları uygulanmış, ardından da Granger nedensellik testi yapılmıştır. Bu bağlamda literatürde yer alan bazı yayınlar taranmışır.

Eğitim ve büyüme arasındaki eşbütünleşme ilişkisini sorgulayan çalışmanın buraya kadar ki bölümünde görüldüğü üzere çalışmanın amacı verilmiştir. Sonraki bölümde literatür taraması ve ardından sırasıyla ekonometrik yöntem ve veri tanımı verilmiştir. Daha sonra uygulama bulguları ve buna bağlı olarak da sonuç kısmına değinilmiştir.

\section{LITERATÜR TARAMASI}

Eğitim ve büyüme arasındaki ilişkiyi araştıran birçok çalışma vardır. Bu çalışmalar iki grupta toplanabilir. Birincisi; eğitim harcamaları/yatırımları, farklı seviyelerdeki okullara kayıtlı öğrenci sayısı vb. nicel değişkenler ile büyümenin ilişkilendirildikleri çalışmalardır. Bu bağlamda Romer (1989), Barro (1991), Mankiw vd. (1992) vb. yazarlar tarafindan yapılan çalışmalar örnek olarak gösterilebilir. İkincisi ise; eğitimdeki başarı oranı gibi nitel değişkenler ile büyümenin ilişkilendirildikleri çalışmalardır. Bunlara da Barro (2001), Tarı (2016) birer örnek teşkil ederler. Konu ile ilgili daha geniş literatür çalışması Tablo 1'de verilmiştir.

Tablo 1: Literatür Taraması

\begin{tabular}{|c|c|c|c|}
\hline Yazar(lar) & $\begin{array}{l}\text { Kapsadı̆̆ } \\
\text { Ülke(ler) ve } \\
\text { Periyot }\end{array}$ & $\begin{array}{l}\text { Kullanılan } \\
\text { Analiz }\end{array}$ & Elde Edilen Ampirik Bulgular \\
\hline Romer (1989) & $\begin{array}{l}112 \text { Ülke } \\
1960-1985\end{array}$ & -E.K.K. & $\begin{array}{l}\text { Okur-yazarlık ve büyüme arasında } \\
\text { pozitif yönlü bir ilişki saptanmıştır. }\end{array}$ \\
\hline Barro (1991) & $\begin{array}{l}98 \text { Ülke } \\
1960-1985\end{array}$ & $\begin{array}{l}\text {-Panel Veri } \\
\text { Analizi }\end{array}$ & $\begin{array}{l}\text { İlköğretime kayıt oranının, büyüme } \\
\text { üzerinde pozitif yönlü bir etki bıraktığ } \\
\text { bulunmuștur. }\end{array}$ \\
\hline $\begin{array}{l}\text { Mankiw vd. } \\
\text { (1992) }\end{array}$ & $\begin{array}{l}121 \text { Ülke } \\
1960-1985\end{array}$ & -E.K.K. & $\begin{array}{l}\text { Ortaöğretime kayıtlı öğrenci sayısının } \\
\text { nüfus içerisindeki payı arttıkça, } \\
\text { eğitimin büyümeyi pozitif yönlü olarak } \\
\text { etkilediği gözlemlenmiştir. }\end{array}$ \\
\hline $\begin{array}{l}\text { Barro ve Lee } \\
\quad(2000)\end{array}$ & $\begin{array}{l}142 \text { Ülke } \\
1960-2000\end{array}$ & $\begin{array}{l}\text {-Panel Veri } \\
\text { Regresyon } \\
\text { Analizi }\end{array}$ & $\begin{array}{l}\text { Eğitimin, ekonomik büyümeyi pozitif } \\
\text { yönlü olarak etkilediği tespit edilmiştir. }\end{array}$ \\
\hline Barro (2001) & $\begin{array}{l}100 \text { Ülke } \\
1960-1995\end{array}$ & $\begin{array}{l}\text {-Panel Veri } \\
\text { Analizi }\end{array}$ & $\begin{array}{l}25 \text { taş üstü erkeklerin eğitim süresi ile } \\
\text { büyüme arasında pozitif yönlü bir ilişki } \\
\text { söz konusuyken; kadınların eğitim }\end{array}$ \\
\hline
\end{tabular}




\begin{tabular}{|c|c|c|c|}
\hline & & & $\begin{array}{l}\text { süresi ile büyüme ilişkisi ise } \\
\text { anlamsızdır. Ayrıca fen ve matematik } \\
\text { derslerine ait sonuçlardaki yükselmenin } \\
\text { ekonomik büyümeyi pozitif yönlü } \\
\text { olarak etkilediği ortaya konulmuştur. } \\
\text { Ancak Okur-yazarlık oranı ile } \\
\text { ekonomik büyüme ilişkisi anlamsızdır. }\end{array}$ \\
\hline Lin (2003) & $\begin{array}{c}\text { Tayvan } \\
1965-2000\end{array}$ & $\begin{array}{l}- \text { Zaman } \\
\text { Serileri } \\
\text { Analizi }\end{array}$ & $\begin{array}{l}\text { Eğitimin, büyüme üzerinde pozitif } \\
\text { yönlü bir etkisinin olduğu saptanmıştır. } \\
\text { Reel sermaye birikimi ile eğitim ve } \\
\text { teknolojik ilerleme ile eğitim arasında } \\
\text { ise herhangi bir ilişki bulunamamıştır. }\end{array}$ \\
\hline $\begin{array}{l}\text { Taban ve Kar } \\
\text { (2006) }\end{array}$ & $\begin{array}{c}\text { Türkiye } \\
1969-2001\end{array}$ & $\begin{array}{c}\text {-Johansen } \\
\text { eşbütünleşme } \\
\text { Analizi }\end{array}$ & $\begin{array}{l}\text { Bileşik okullaşma endeksinden reel } \\
\text { GSMH'ye doğru bir nedensellik ilişkisi } \\
\text { tespit edilirken; büyüme ile eğitim } \\
\text { endeksi arasinda ise çift yönlü bir } \\
\text { nedensellik ilişkisi gözlemlenmiştir. }\end{array}$ \\
\hline $\begin{array}{l}\text { Aka ve } \\
\text { Dumont } \\
(2008)\end{array}$ & $\begin{array}{c}\text { ABD } \\
1930-1965\end{array}$ & $\begin{array}{l}\text {-VAR } \\
\text { Analizi }\end{array}$ & $\begin{array}{l}\text { Büyüme ve eğitim arasında çift yönlü } \\
\text { bir nedenselliğin bulunduğu ortaya } \\
\text { konmuştur. }\end{array}$ \\
\hline $\begin{array}{l}\text { Baldacci } \\
\text { (2008) }\end{array}$ & $\begin{array}{l}118 \text { Geliş̧mekte } \\
\text { Olan Ülke } \\
\text { 1971-2000 }\end{array}$ & $\begin{array}{c}\text {-Panel Veri } \\
\text { Analizi }\end{array}$ & $\begin{array}{l}\text { Eğitim ve sağlık harcamalarının eğitim } \\
\text { seviyesi ve insan sağlığ üzerinde } \\
\text { pozitif yönlü bir etki bıraktığı ve bu } \\
\text { etkinin de büyümeyi pozitif yönlü } \\
\text { olarak etkilediği saptanmıştır. }\end{array}$ \\
\hline Afşar (2009) & $\begin{array}{c}\text { Türkiye } \\
1963-2005\end{array}$ & $\begin{array}{l}\text {-Granger } \\
\text { Nedensellik } \\
\text { Testi }\end{array}$ & $\begin{array}{l}\text { Eğitim yatırımlarından, ekonomik } \\
\text { büyümeye doğru pozitif yönlü bir etki } \\
\text { tespit edilmiştir. }\end{array}$ \\
\hline $\begin{array}{l}\text { Erdoğan ve } \\
\text { Y1ldırım } \\
(2009)\end{array}$ & $\begin{array}{l}\text { Türkiye } \\
1983-2005\end{array}$ & $\begin{array}{c}\text {-ARDL Sınır } \\
\text { Testi } \\
\text { Yaklaşımı }\end{array}$ & $\begin{array}{l}\text { İlkokul, ortaokul, genel ve meslek } \\
\text { liselerinde bulunan öğretmen - öğrenci } \\
\text { oranları ile ekonomik büyüme ilişkisi } \\
\text { arasında pozitif yönlü bir ilişki } \\
\text { saptanmı̧; buna ek olarak lise ve } \\
\text { yüksekokul düzeyindeki okullaşma } \\
\text { oranı ve eğitim harcamalarnın, } \\
\text { büyüme ile negatif yönlü bir ilişki } \\
\text { içerisinde olduğu gözlemlenmiştir. }\end{array}$ \\
\hline Özsoy (2009) & $\begin{array}{l}\text { Türkiye } \\
1923-2005\end{array}$ & $\begin{array}{c}\text {-VAR } \\
\text { Analizi } \\
\text {-Granger } \\
\text { Nedensellik } \\
\text { Testi }\end{array}$ & $\begin{array}{l}\text { Büyüme ile eğitim arasında } \\
\text { eşbütünleşik bir ilişki tespit edilirken; } \\
\text { eğitim seviyesi yükseldikçe büyüme } \\
\text { üzerindeki etkisinin giderek azaldığ1 } \\
\text { saptanmıştır. Ayrıa Granger } \\
\text { nedensellik analizine göre ilköğretimde } \\
\text { okuyan öğrenci sayısı ile büyüme } \\
\text { arasında çift yönlü; büyümeden } \\
\text { ortaöğretime doğru tek yönlü ve } \\
\text { mesleki eğitimden büyümeye doğru tek } \\
\text { yönlü bir nedensellik söz konusudur. } \\
\text { Ancak yükseköğretim ile büyüme } \\
\text { arasında ise herhangi bir nedensellik } \\
\text { ilişkisi bulunamamıştır. }\end{array}$ \\
\hline
\end{tabular}




\begin{tabular}{|c|c|c|c|}
\hline $\begin{array}{c}\text { Bozkurt } \\
(2010)\end{array}$ & $\begin{array}{l}\text { Türkiye } \\
\text { 1980-2005 }\end{array}$ & $\begin{array}{c}\text {-Engle } \\
\text { Granger Testi } \\
\text {-Joansen } \\
\text { Eşbütünleşme } \\
\text { Testi } \\
\text {-Stock } \\
\text { Watson Testi }\end{array}$ & $\begin{array}{l}\text { Ayr1 ayrı olarak analize tabi tutulan } \\
\text { eğitim ve sağlığın büyüme üzerinde } \\
\text { pozitif yönlü bir etki bıraktıkları } \\
\text { saptanmıştır. Ancak eğitim ve sağllk } \\
\text { birlikte ele alındıklarında ise büyüme } \\
\text { üzerinde sağlığın daha etkili olduğu } \\
\text { gözlemlenmiștir. }\end{array}$ \\
\hline $\begin{array}{l}\text { Çalışkan vd. } \\
\quad(2013)\end{array}$ & $\begin{array}{l}\text { Türkiye } \\
1923-2011\end{array}$ & $\begin{array}{l}\text {-Johansen } \\
\text { Eşbütünleşme } \\
\text { Testi }\end{array}$ & $\begin{array}{l}\text { İlkokulda öğrenim gören öğrenci sayıs1 } \\
\text { ile büyüme arasında negatif yönlü; lise, } \\
\text { teknik lise ve yükseköğretime kayıtlı } \\
\text { öğrenci sayısı ile büyüme arasında ise } \\
\text { pozitif yönlü bir ilişki olduğu } \\
\text { saptanmıştır. Ayrıa bu sonuçlara ait } \\
\text { katsayılarda lise seviyesindeki öğrenci } \\
\text { sayısında meydana gelecek \%1'lik bir } \\
\text { artışın GSYIH'yi yaklaş1k olarak \% } 0,2 \\
\text { oranında ve yükseköğretim } \\
\text { seviyesindeki \%1'lik bir artı̧ı ise } \\
\text { GSYİH'yi \% } 3 \text { oranında artırdığ } \\
\text { gözlemlenmiştir. }\end{array}$ \\
\hline $\begin{array}{c}\text { Eriçok ve } \\
\text { Y1lanc1 (2013) }\end{array}$ & $\begin{array}{l}\text { Türkiye } \\
1968-2005\end{array}$ & $\begin{array}{l}\text {-ARDL Sınır } \\
\text { Testi } \\
\text { Yaklaşımı } \\
\end{array}$ & $\begin{array}{l}\text { Eğitim harcamalarının, büyüme } \\
\text { üzerinde kısa dönemli bir etkisinin } \\
\text { bulunduğu tespit edilmiştir. }\end{array}$ \\
\hline $\begin{array}{c}\text { Çetin ve } \\
\text { Yakış1k (2014) }\end{array}$ & $\begin{array}{l}\text { Türkiye } \\
1980-2012\end{array}$ & $\begin{array}{l}\text {-ARDL Sınır } \\
\text { Testi } \\
\text { Yaklaşımı }\end{array}$ & $\begin{array}{l}\text { Patent sayısı, ortalama yaşam süresi ve } \\
\text { ortaögretim okullaşma oranının } \\
\text { büyüme üzerinde pozitif yönlü bir } \\
\text { etkisi olduğu gözlemlenirken; } \\
\text { yükseköğretimin büyüme üzerinde } \\
\text { olası bir etkisine rastlanmamıştır. }\end{array}$ \\
\hline $\begin{array}{l}\text { Kızılkaya ve } \\
\text { Koçak (2014) }\end{array}$ & $\begin{array}{l}11 \text { OECD Ülkesi } \\
\text { 1990-2009 }\end{array}$ & $\begin{array}{l}\text {-Panel } \\
\text { Eşbütünleşme } \\
\text { Analizi } \\
\end{array}$ & $\begin{array}{llr}\text { Eğitim harcamalarının } & \text { büyümeyi } \\
\text { pozitif yönlü olarak } & \text { etkilediği } \\
\text { bulunmuştur. } & & \\
\end{array}$ \\
\hline $\begin{array}{l}\text { Yardımcıoğlu } \\
\quad(2014)\end{array}$ & $\begin{array}{l}25 \text { OECD Ülkesi } \\
1980-2008\end{array}$ & $\begin{array}{l}\text { Panel } \\
\text { Eşbütünleşme } \\
\text { ve } \\
\text { Nedensellik } \\
\text { Testleri } \\
\end{array}$ & $\begin{array}{l}\text { Eğitim harcamaları ile büyüme arasında } \\
\text { çift yönlü bir ilişkiye rastlanmıştır. }\end{array}$ \\
\hline $\begin{array}{l}\text { Bozkurt } \\
(2015)\end{array}$ & $\begin{array}{c}\text { Türkiye } \\
\text { 1998:1-2014:3 }\end{array}$ & $\begin{array}{l}\text {-Johansen } \\
\text { Juselius } \\
\text { Eşbütünleşme } \\
\text { Analizi } \\
\end{array}$ & $\begin{array}{l}\text { Bilgi, eğitim ve sağlık sektörlerindeki } \\
\text { çıktının, büyümeyi pozitif yönlü olarak } \\
\text { etkilediği tespit edilmiştir. }\end{array}$ \\
\hline $\begin{array}{l}\text { Tarı ve } \\
\text { Beşballı } \\
\text { (2016) }\end{array}$ & $\begin{array}{l}\text {-1. Modelde } 64 \\
\text { Ülke / 1995-2011 } \\
\text {-2. Modelde } 43 \\
\text { Ülke / 2001-2011 } \\
\text {-3. Modelde } 53 \\
\text { Ülke / 2000-2009 }\end{array}$ & $\begin{array}{l}\text { Panel Veri } \\
\text { Regresyon } \\
\text { Analizi }\end{array}$ & $\begin{array}{l}\text { Her üç modelde de eğitime ait nitel } \\
\text { faktörlerin, büyüme üzerinde nicel } \\
\text { faktörlerden daha fazla etkili olduğu } \\
\text { gözlemlenmiştir. }\end{array}$ \\
\hline
\end{tabular}




\begin{tabular}{|c|c|c|c|}
\hline $\begin{array}{c}\text { Terzi ve } \\
\text { Yurtkuran } \\
\text { (2016) }\end{array}$ & $\begin{array}{l}\text { Türkiye } \\
\text { 1950-2012 }\end{array}$ & $\begin{array}{c}\text {-Sims ve } \\
\text { Toda } \\
\text { Yamamoto } \\
\text { Nedensellik } \\
\text { Analizleri } \\
\text {-Varyans } \\
\text { Ayrıştırma } \\
\text { Testleri } \\
\text {-Etki Tepki } \\
\text { Fonksiyonları }\end{array}$ & $\begin{array}{l}\text { Büyümeden, üniversite mezunu öğrenci } \\
\text { sayısına doğru pozitif yönlü bir } \\
\text { nedensellik saptanırken; lise ve meslek } \\
\text { lisesi mezunu sayısından büyümeye } \\
\text { doğru ise pozitif yönlü bir nedensellik } \\
\text { bulunmuştur. }\end{array}$ \\
\hline $\begin{array}{l}\text { Uçan ve } \\
\text { Yeşilyurt } \\
\text { (2016) }\end{array}$ & $\begin{array}{c}\text { Türkiye } \\
\text { 2006:1-2015:4 }\end{array}$ & $\begin{array}{l}\text {-Johansen } \\
\text { Eşbütünleşme } \\
\text { ve Granger } \\
\text { Nedenselillik } \\
\text { Testleri }\end{array}$ & $\begin{array}{l}\text { Eğitim ve büyüme arasında uzun } \\
\text { dönemli bir ilişki gözlemlenirken; } \\
\text { Granger Nedensellik Testi’ne göre de } \\
\text { eğitim ve büyüme arasında çift yönlü } \\
\text { bir nedensellik ilişkisi saptanmıştır. }\end{array}$ \\
\hline
\end{tabular}

Literatür taramasında görüldüğü üzere, yapılan ampirik çalışmalarda genel olarak ekonomik büyümeyle eğitim arasında pozitif yönlü bir ilişki tespit edilmiştir. $\mathrm{Bu}$ etkinin Türkiye'yi ele alan çalışmalarda da tespit edildiği gözlemlenmektedir. Ayrıca çalışmaların çoğunluğunda kullanılan nedensellik testleri de, eğitim ile büyüme arasında çift yönlü bir nedenselliğe işaret etmektedir.

\section{EKONOMETRİK YÖNTEM}

Zaman serileri, durağan olabileceği gibi durağan olmayan süreçlere de sahip olabilirler. Durağan olmayan zaman serileri ile analiz yapılması durumunda ise olası bir sahte regresyon sorunu ile karşılaşlabilir. Bunu engelleyerek durağan olmayan serileri durağan hale getirmek amaciyla serilerin farkları alınır (Gujarati ve Porter, 2012: 737-741,760). Buna ek olarak değişkenler arasındaki olası uzun dönem ilişkilerin ortaya çıkarılabilmesi için de eşbütünleşme testleri kullanılmaktadır. Ancak klasik eşbütünleşme testlerinin uygulanabilmesi için değişkenlerin aynı dereceden bütünleşik olması gerekir. Bu durum da doğal olarak eşbütünleşme testlerinin uygulanabilirliğini sınırlamaktadır. ARDL yöntemi ile yapılacak analizlerde ise serilerin aynı dereceden bütünleşik olmaması bir problem oluşturmaz. Analizin uygulanabilmesi için serilerin, iki veya daha üst derecelerde bütünleşik olmaması yeterlidir. Yine ARDL yöntemi; kısa ve uzun dönem parametrelerini birlikte tahminleyebilmesi ve VAR analizi'nin aksine serilerin farklı gecikme uzunluklarında bulunabilmesine imkân tanıması gibi özellikleriyle de diğer analizlere göre bir takım üstünlüklere sahiptir (Pesaran, 2001).

Analizde kullanılan iktisadi fonksiyon şu şekildedir:

$$
l y=f(l K, l L, e d u c)
$$

Yukarıdaki iktisadi fonksiyondan ARDL yöntemi için oluşturulan (1) no'lu ekonometrik model ise aşağıdaki gibidir:

$$
\begin{aligned}
& \Delta l y_{t}=\beta_{0}+\sum_{i=1}^{p} \beta_{i} \Delta l y_{t-i}+\sum_{i=0}^{q} \alpha_{i} \Delta l K_{t-i}+\sum_{i=0}^{r} \delta_{i} \Delta l L_{t-i}+\sum_{i=0}^{m} \lambda_{i} \Delta e d u c_{t-i}+\theta_{0} l Y_{t-1}+ \\
& \theta_{1} l K_{t-1}+\theta_{2} l L_{t-1}+\theta_{3} e d u c_{t-1}+\varepsilon_{t}
\end{aligned}
$$


(1) no'lu modelde Türkiye'de 1980-2013 periyodunu ele alan ly serisi, büyümeyi temsilen dolar cinsinden kişi başı GSYİH'nin logaritmik dönüşümünü; $1 \mathrm{~K}$ serisi, sabit sermayenin milli gelire oranının logaritmasını; lL değişkeni, istihdam oranının logaritmik dönüşümünü ve educ serisi ise eğitimi temsilen ortaokullaşma düzeyini göstermektedir. Yine modeldeki $\theta_{0}, \theta_{1}$ ve $\theta_{2}$ katsayıları seriler arasındaki uzun dönem ilişkileri tanımlarken; $\beta_{i}, \alpha_{i}, \delta_{i}$ ve $\lambda_{i}$ katsayıları ise seriler arasındaki kısa dönem ilişkileri açıklamaktadır. Ayrıca $\Delta$ birinci dereceden fark operatörü, $\beta_{0}$ modelin sabit terimi ve $\varepsilon_{t}$ modelin beyaz gürültü hata terimi olarak ifade edilebilir.

ARDL sınır testi yaklaşımında uzun ve kısa dönemli ilişkilerin tahmin edilebilmesi birkaç adımda gerçekleştirilir. İlk olarak model (1) tahmin edilir. Bu bağlamda yapılacak işlem, seriler arasında olası bir uzun dönem ilişkisinin varlığını sorgulamak amacıyla gecikmeli serilerin katsayılarının tümünün aynı anda sıfıra eşit olduğunu varsayan $H_{0}$ hipotezinin $\mathrm{F}$ testi ile sınanmasıdır. F testi sınaması ile bulunan sonuç, seriler arasında uzun dönemde bir ilişki olmadığı ya da diğer bir ifadeyle eşbütünleşmenin bulunmadığı yönündeyse, $H_{0}: \theta_{0}=\theta_{1}=\theta_{2}=0$ şeklinde ifade edilen $H_{0}$ hipotezi reddedilemez. Aksine eğer seriler arasında uzun dönemde eşbütünleşik bir ilişki tespit edilmiş ise bu kez de $H_{1}: \theta_{0} \neq \theta_{1} \neq \theta_{2} \neq 0$ şeklindeki $H_{1}$ hipotezi kabul edilir. Burada $\mathrm{F}$ testi ile tahmin yapilırken Pesaran vd. (2001) tarafindan belirlenmiş olan alt ve üst sınır değerleri bağlamında karar verilir. Daha açı bir ifadeyle bulunan $\mathrm{F}$ testi'ne ait değer, eğer tablo üst değerinden büyükse $H_{1}$ hipotezi kabul edilerek $H_{0}$ hipotezi reddedilir. Tersine $\mathrm{F}$ testi'ne ait değer, eğer tablo alt değerinden küçükse $H_{0}$ hipotezi kabul edilerek $H_{1}$ hipotezi reddedilir. Bulunan $\mathrm{F}$ testi sonucunun alt ve üst değerler arasında bulunması durumunda ise karar verilemez.

İlk adımda uygulanan sınır testi sonucunda seriler arasında eşbütünleşme ilişkisi tespit edilmiş ise ikinci adıma geçilerek, farklı model seçim kriterlerinden birinin kullanılmasıyla seriler için en uygun gecikme uzunlukları tespit edilir. Burada en uygun gecikmeli model ARDL $(\mathrm{p}, \mathrm{q}, \mathrm{r}, \mathrm{m})$ olarak varsay1lır. Yani " $p$ ", ly serisinin; " $q$ ", $1 \mathrm{~K}$ serisinin; " $r$ ", $1 \mathrm{~L}$ serisinin ve " $m$ " ise educ serisinin gecikme uzunluklarıdır.

Üçüncü ve son adımda ise en uygun gecikme uzunlukları bağlamında hata düzeltme modeli belirlenir. Tahmin edilen (2) no'lu hata düzeltme modeli aşağıdaki gibidir:

$$
l y_{t}=\beta_{0}+\sum_{i=1}^{p} \beta_{i} \Delta l y_{t-i}+\sum_{i=0}^{q} \alpha_{i} \Delta l K_{t-i}+\sum_{i=0}^{r} \delta_{i} \Delta l L_{t-i}+\sum_{i=0}^{m} \lambda_{i} \Delta e d u c_{t-1}+\varphi E C M_{t-1}+\varepsilon_{t}
$$

Yukarıdaki (2) no'lu modelde $\beta_{i}, \alpha_{i}, \delta_{i}$ ve $\lambda_{i}$ katsayıları, modeli dengeye getiren dinamik katsayıları ifade ederken; $E C M$ hata düzeltme terimi ve $\varphi$ terimi ise k1sa dönemde meydana gelen bir şok sebebiyle uzun dönemde modelin yeniden dengeye evrilme hızını gösterir. Ancak $\varphi$ teriminin bu açıklayıcılığa sahip olabilmesi için her şeyden önce istatistiksel olarak anlamlı olması gerekir.

Daha sonra Johansen eşbütünleşme yaklaşımı uygulanmıştır. Sistem yaklaşımı olan Johansen (1988), iz testi ve maksimum öz değerleri dikkate alınarak yapılmaktadır. Bu yaklaşım için iz testi şu şekilde ifade edilmektedir:

$$
-2 \operatorname{I} n(Q)=-T \sum_{i=1+r}^{p} \operatorname{In}\left(1-\lambda_{i}\right)
$$


Yukarıdaki denklemde $\lambda_{\mathrm{i}}$ tahmin edilen öz değerlerdir. Modelin boş hipotezi rank $\leq \mathrm{r}$ olup, aleyhinde kanıt aradığımız alternatif hipotez ise rank $\geq r+1$ şeklinde ifade edilmektedir. Maksimum öz değer yaklaşımında ise sıfir hipotezi $r$ eşbütünleşme vektörünü içerdiği, alternatif hipotez de r+1 eşbütünleşme vektörü bulunmaktadır (Feridun ve Sissoko, 2011).

Çalışmada, seriler arasındaki olası nedensellik ilişkisinin sorgulanması ve nedensellik ilişkisi bulunması durumunda da bu ilişkinin yönünün belirlenmesi amacıyla Toda-Yamamoto yaklaşımı ile Granger nedensellik testi uygulanmıştır. Bilindiği üzere Toda-Yamamoto testinin yapılabilmesi için ilk olarak serilerin maksimum bütünleşme derecelerinin (dmax) saptanması gerekir. Daha sonra ise kısıtsız VAR modeli kurulur. Bunun akabinde ise model seçim kriterleri kullanılarak kurulan bu modele en uygun gecikme uzunluğu saptanır. En uygun modelin VAR(P) olduğu varsayılır. Bu varsayım altında da VAR (P+dmax) modeli tahmin edilerek, VAR $(\mathrm{P}+\mathrm{dmax})$ Modeli için VAR Granger nedensellik testi uygulanır. VAR Granger nedensellik testi bulguları bağlamında da değişkenler arasındaki nedensellik ilişkisinin olası yönü tahmin edilir.

\section{VERI TANIMI}

1980-2013 yıllarını kapsayan modelin değişkenleri: dolar olarak kişi başına düşen gelir (y), sermaye (K), emek (L) ve eğitim (educ) düzeyidir. Sermaye değişkeni sabit sermayenin milli gelire oranı, emek değişkeni ise istihdam oranı olarak tanımlanmıştır. Eğitim düzeyini ifade eden değişken ise ortaokullaşma düzeyi ile gösterilmiştir. Gelir, sermaye ve emek değişkenlerinin logaritma formu kullanılmıştır. Ayrıca eğitim değişkenine ait verilerin 2013 yılına kadar ulaşılabilmesinden dolay1 1980-2013 dönemi için modelleme yapılmıştır. Gelir ve eğitim değişkenlerine ait veriler Dünya Bankası, sermaye ve emek değişkenlerinin verileri ise Kalkınma Bakanlığı Ekonomik ve Sosyal Göstergelerden temin edilmiştir. Şekil 1'de değişkenlere ait grafiklere yer verilmiştir.

LY
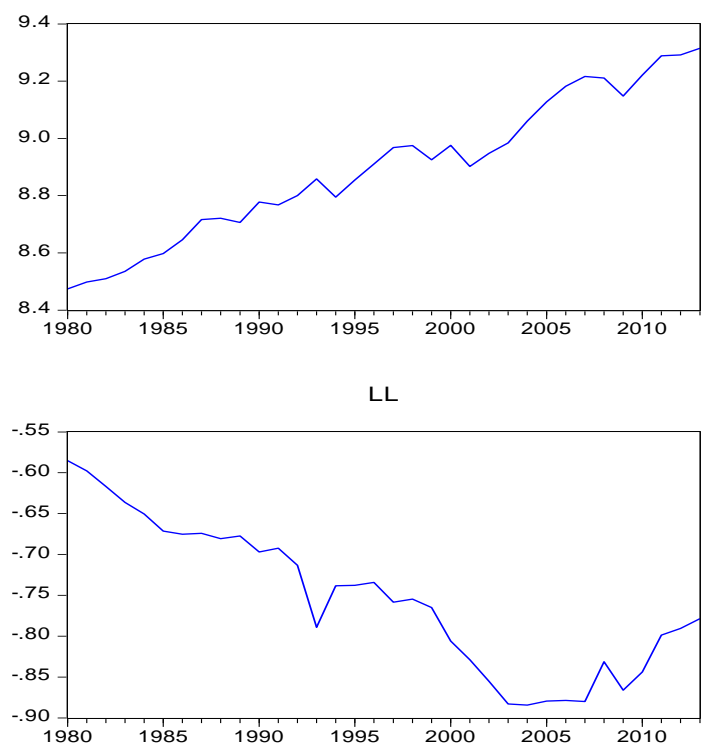

LK

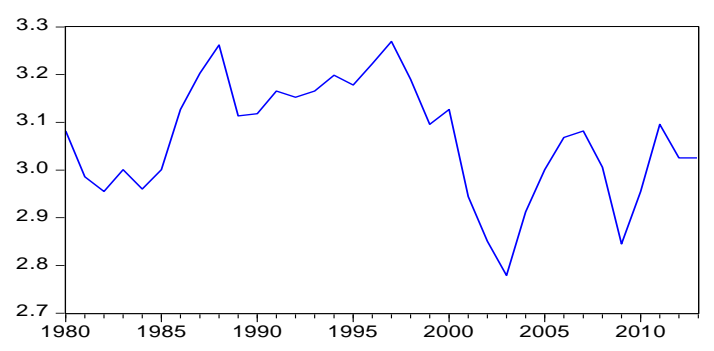

EDUC

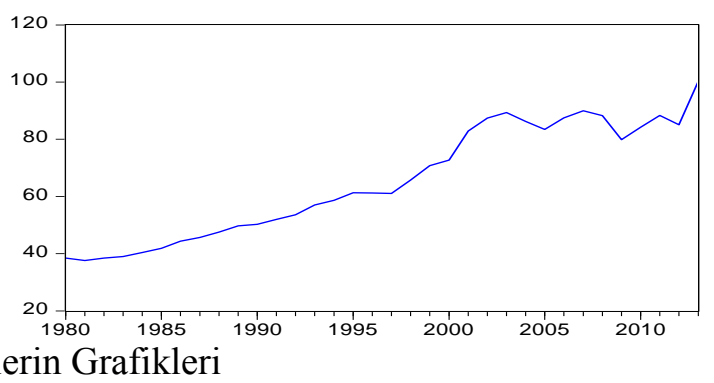

Yukarıdaki grafiklerden de anlaşılacağı üzere, değişkenlerin durağan olmadığı görülmektedir. Diğer bir ifadeyle, serilerin ortalama ve varyansının zamana bağlı olarak değiştiğini söyleyebiliriz. 
Tablo 2: Özet İstatistikler

\begin{tabular}{cccccc}
\hline Değişkenler & Gözlem & Ortalama & Std. Sapma & Min. & Maks. \\
\hline$l y$ & 34 & 8.89 & 0.25 & 8.47 & 9.31 \\
$l K$ & 34 & 3.06 & 0.12 & 2.77 & 3.26 \\
$l L$ & 34 & -0.75 & 0.09 & -0.88 & -0.58 \\
$e d u c$ & 34 & 65.30 & 19.63 & 37.62 & 100.27 \\
\hline
\end{tabular}

Tablo 2'de değişkenlerin tanımlayıcı özelliklerini görebilmek amacıyla özet istatistiklerine yer verilmiştir.

\section{UYGULAMA BULGULARI}

Peseran vd. (2001), ARDL yaklaşımında kullanılacak değişkenlerin I(0) ya da I(1) olması gerektiğini varsaymaktadır. Bu nedenle, serilerin durağan olup olmadıklarını tespit edebilmek için birim kök testleri yapılmıştır. Tablo 3 ve Tablo 4'de sırasıyla ADF ve DF-GLS birim kök testleri yer almaktadır.

Tablo 3: ADF Birim Kök Test Sonuçları

\begin{tabular}{ccccccc}
\hline Değișkenler & \multicolumn{3}{c}{ Sabit } & \multicolumn{3}{c}{ Sabit ve Trend } \\
\hline$l y$ & Gecikme S. & ADF & p-değeri & Gecikme S. & ADF & p-değeri \\
$\Delta l y$ & 4 & -0.532 & 0.8857 & 4 & -3.17 & 0.10 \\
$l K$ & 4 & -6.38 & 0.000 & 4 & -6.27 & 0.0001 \\
$\Delta l K$ & 4 & -2.04 & 0.26 & 4 & -2.85 & 0.18 \\
$l L$ & 4 & -4.79 & 0.0005 & 4 & -4.73 & 0.0032 \\
$\Delta l L$ & 4 & -1.97 & 0.29 & 4 & -0.65 & 0.98 \\
$e d u c$ & 4 & -5.70 & 0.000 & 4 & -6.29 & 0.0001 \\
$\Delta e d u c$ & 4 & 0.02 & 0.95 & 4 & -3.04 & 0.13 \\
\hline
\end{tabular}

Tablo 3'de yer alan ADF birim kök test sonuçlarına göre, değişkenler düzeyde değil ancak birinci farklarda durağandır. Diğer bir ifadeyle seriler I(1) özelliği taşımaktadır.

Tablo 4: DF-GLS Birim Kök Test Sonuçları

\begin{tabular}{ccccccc}
\hline Değişkenler & & Sabit & \multicolumn{3}{c}{ Sabit ve Trend } \\
\hline & Gecikme S. & DF-GLS & Kritik & Gecikme S. & DF-GLS & Kritik \\
$l y$ & 4 & 0.73 & -2.63 & 4 & -3.26 & Değer \\
$\Delta l y$ & 4 & -6.48 & -2.63 & 4 & -6.48 & -3.77 \\
$l K$ & 4 & -2.07 & -2.63 & 4 & -2.18 & -3.77 \\
$\Delta l K$ & 4 & -4.30 & -2.63 & 4 & -4.66 & -3.77 \\
$l L$ & 4 & -0.92 & -2.63 & 4 & -1.09 & -3.77 \\
$\Delta l L$ & 4 & -5.78 & -2.63 & 4 & -6.48 & -3.77 \\
$e d u c$ & 4 & 0.71 & -2.63 & 4 & -2.40 & -3.77 \\
$\Delta e d u c$ & 4 & -4.76 & -2.63 & 4 & -4.36 & -3.77 \\
\hline
\end{tabular}

Tablo 4'de yer alan DF-GLS birim kök test sonuçları da ADF birim kök test sonuçlarını desteklemektedir. Değişkenlerin düzey değerlerinin değil, birinci farklarının durağan oldukları görülmektedir.

Daha sonra, ARDL yaklaşımı için uygun gecikme uzunlukları belirlenmiştir. Söz konusu gecikme uzunluğu Akaiki Bilgi Kriteri dikkate alınarak ARDL $(3,3,3,4)$ olarak tespit edilmiştir ve Şekil 2'de gösterilmiştir. 


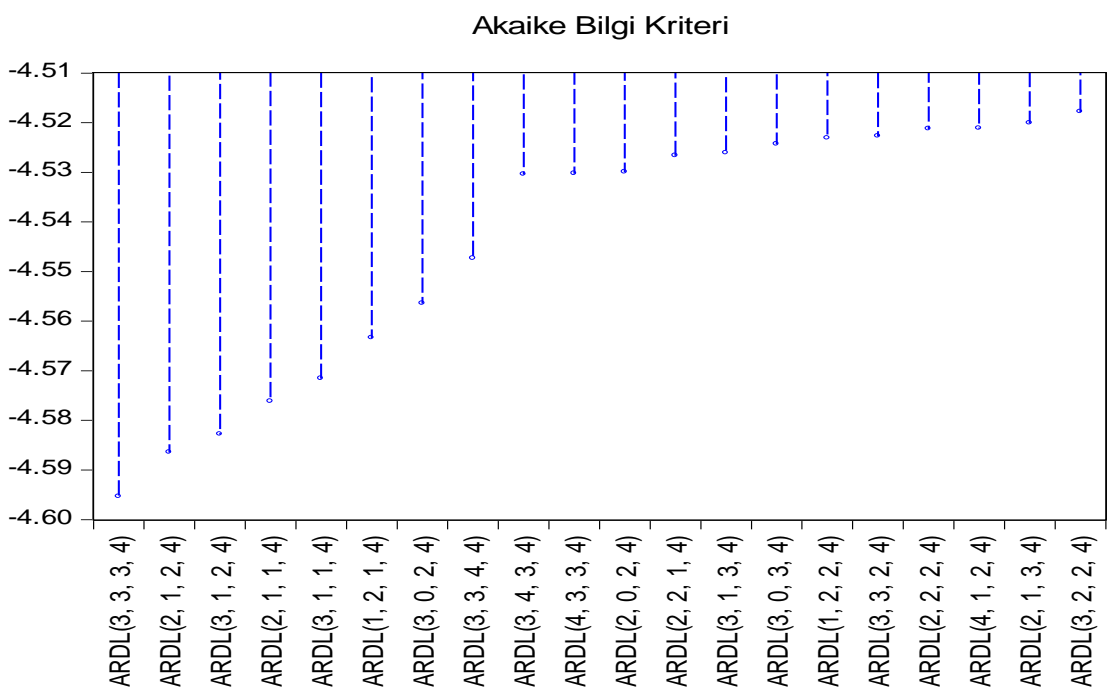

Şekil 2: Sınır Testi için Gecikme Uzunluğunun Tespiti

Gecikme uzunlukları belirlendikten sonra, eşbütünleşme ilişkisinin varlığının tespiti için Tablo 5'de sınır test sonuçları verilmiştir.

Tablo 5: Eşbütünleşme Test Sonuçları

\begin{tabular}{cccc}
\hline $\mathbf{k}$ & F-istatistiği & Alt Sınır ( \%5 için) & Üst Sınır (\% 5 için) \\
\hline 3 & 7.54 & 3.23 & 4.35
\end{tabular}

Tablo 5'de yer alan eşbütünleşme test sonuçlarına göre hesaplanan F-istatistiği \% 5 anlamlılık düzeyinde üst sınırın üzerinde yer almaktadır. Peseran vd. (2001) varsayımı göz önüne alındığında eşbütünleşmenin olmadığını ifade eden boş hipotezi reddederek, seriler "eşbütünleşiktir" diyebiliriz. Bu ilişkinin varlığının tespitinden sonra Tablo 6'da uzun dönem büyüme modeli verilmiştir.

Tablo 6: ARDL $(3,3,3,4)$ Modeli Uzun Dönem Sonuçları (Bağımlı Değiş̧ken: ly)

\begin{tabular}{cccc}
\hline Değişken & Katsayı & t-istatistiği & p-değeri \\
\hline$l K$ & 0.511 & 6.284 & $0.000^{* * *}$ \\
$l L$ & 2.312 & 4.185 & $0.001^{* * *}$ \\
$e d u c$ & 0.024 & 8.341 & $0.000^{* * *}$ \\
Sabit & 7.624 & 31.898 & $0.000^{* * *}$ \\
\hline
\end{tabular}

Not: Anlaml111k düzeyleri: ${ }^{*} \mathrm{p}<0.1,{ }^{* *} \mathrm{p}<0.05,{ }^{* * *} \mathrm{p}<0.01$

Tablo 6'de yer alan ARDL $(3,3,3,4)$ uzun dönem tahmin sonuçlarına göre istatistiki olarak anlamlı olan eğitim değişkeni ekonomik büyümeyi artırmaktadır. Bu da 1980-2013 döneminde eğitim düzeyi arttıkça Türkiye Ekonomisine ait kişi başına düşen gelir artış göstermektedir. Uzun dönem modeline göre, Türkiye'de yaşayanların eğitim düzeyi 1 yıl yükseldiğinde kişi başına düşen gelir \% 2 artış göstermektedir.

Diğer yandan, uzun dönem denkleminde yer alan sermaye ve istihdam değişkenleri istatistiksel olarak anlamlı olmakla birlikte, büyüme üzerinde olumlu etki yapmaktadır. Yani, sabit sermaye ve istidam oranı \% 1 arttığında, gelir de sirasıyla \% 0.5 ve \% 2.3 artmaktadır. Modelin kısa dönem bulguları ise Tablo 7'de verilmiştir. 
Tablo 7: ARDL (3,3,3,4) Hata Düzeltme Modelinin Sonuçları

\begin{tabular}{cccc}
\hline \hline Değişkenler & Katsayı & Standart Hata & t-istatistiği[p-değeri] \\
\hline$\Delta \mathrm{ly}_{\mathrm{t}-1}$ & -0.3169 & 0.1771 & $-1.7892[0.09]^{*}$ \\
$\Delta \mathrm{y}_{\mathrm{t}-2}$ & -0.3850 & 0.1908 & $-2.0174[0.06]^{*}$ \\
$\Delta \mathrm{lK}^{\mathrm{K}}$ & 0.5226 & 0.0749 & $6.9715[0.00]^{* * *}$ \\
$\Delta \mathrm{K}_{\mathrm{t}-1}$ & -0.1335 & 0.1257 & $-1.0625[0.30]$ \\
$\Delta \mathrm{K}_{\mathrm{t}-2}$ & 0.1746 & 0.1021 & $1.7087[0.11]$ \\
$\Delta \mathrm{lL}$ & 0.1367 & 0.2152 & $0.6354[0.53]$ \\
$\Delta \mathrm{L}_{\mathrm{t}-1}$ & -0.4992 & 0.3454 & $-1.4452[0.17]$ \\
$\Delta \mathrm{L}_{\mathrm{t}-2}$ & -0.5797 & 0.4157 & $-1.3942[0.18]$ \\
$\Delta \mathrm{educ}^{\mathrm{educ}}$ & 0.0000 & 0.0015 & $0.0103[0.99]$ \\
$\Delta \mathrm{educ}_{\mathrm{t}-2}$ & -0.0061 & 0.0029 & $-2.0822[0.05]^{* *}$ \\
$\Delta \mathrm{educ}_{\mathrm{t}-3}$ & -0.0018 & 0.0025 & $-0.7190[0.48]$ \\
$\mathrm{ECM}(-1)$ & -0.0070 & 0.0022 & $-3.0754[0.008]^{* * *}$ \\
\hline \hline
\end{tabular}

Not: Anlamll11k düzeyleri: * $\mathrm{p}<0.1, * * \mathrm{p}<0.05,{ }^{* * *} \mathrm{p}<0.01$

Hata düzeltme modelinin sonuçlarına göre, hata düzeltme katsayısı (ECM(-1)) \% 1 düzeyinde anlamlı ve katsayı değeri negatiftir. Bu sonuç ile değişkenler "eşbütünleşiktir" diyebiliriz. Katsayı değerlerine bakıldığında da kısa dönemde anlamlı olan değişken, sermaye değişkenidir. Ve kısa dönemde de sermaye düzeyi arttığında büyüme de artmaktadır.

Tablo 8: Johansen Eşbütünleşme Test sonuçları

\begin{tabular}{cccc}
\hline \hline Maksimum rank & Özdeğer & İz İstatistiği & 5\% Kritik Değer \\
\hline 0 & - & 53.4580 & 47.21 \\
1 & 0.6605 & $18.8906^{*}$ & 29.68 \\
2 & 0.3280 & 6.1695 & 15.41 \\
3 & 0.1753 & 0.0009 & 3.76 \\
\hline \hline
\end{tabular}

Daha sonra sistem yaklaşımı olan Johansen testi uygulanmıştır. Tablo 8'de de görüldüğü üzere, eşbütünleşmenin olmadığını ifade eden boş hipotez reddedilmiştir. Bu durumda değişkenler arasında uzun dönemli bir ilişkinin varllğı ispat edilmiştir.

Tablo 9: DOLS Tahmini

\begin{tabular}{cccc}
\hline Değişken & Katsayı & t-istatistiği & p-değeri \\
\hline$l K$ & 0.1440 & 1.7562 & $0.0952^{*}$ \\
$l L$ & 0.8104 & 28.8411 & $0.000^{* * *}$ \\
$e d u c$ & 0.0063 & 12.6109 & $0.000^{* * *}$ \\
\hline
\end{tabular}

Not: Anlaml11ık düzeyleri: ${ }^{*} \mathrm{p}<0.1,{ }^{* *} \mathrm{p}<0.05,{ }^{* * *} \mathrm{p}<0.01$

Değişkenler arasında koentegrasyonun varlığı Tablo 8'da gösterilmiş, ardından katsayı tahmini için dinamik OLS tahmini yapılmış ve Tablo 9'da verilmiştir. Buna göre, değişkenler istatistiki olarak anlamlı bulunmuştur. Sermaye, emek ve eğitim değişkenlerinin milli gelir üzerinde pozitif bir etki yaptığı görülmektedir.

Uzun dönemde birlikte hareket ettiği tespit edilen değişkenler için nedensellik analizi yapılmıştır. Granger nedensellik testi için Toda-Yamamoto yaklaşımı kullanılmış ve Tablo 10'da verilmiş̧ir. 
Tablo 10: Granger Nedensellik Testi / Toda-Yamamoto Yaklaşımı

\begin{tabular}{cccc}
\hline \hline \multicolumn{4}{c}{ Bağımlı Değişken: ly } \\
\hline Dışlanan & Ki-Kare & Serbestlik Derecesi & P-değeri \\
IK & 148.3864 & 5 & 0.0000 \\
IL & 151.8324 & 5 & 0.0000 \\
educ & 193.2654 & 5 & 0.0000 \\
Tümü & 639.7801 & 15 & 0.0000 \\
\hline \hline \multicolumn{4}{c}{ Bağımlı Değişken: educ } \\
\hline Dışlanan & Ki-Kare & Serbestlik Derecesi & P-değeri \\
ly & 1.9158 & 5 & 0.8607 \\
lK & 2.5689 & 5 & 0.7661 \\
IL & 5.5183 & 5 & 0.3559 \\
Tümü & 9.6443 & 15 & 0.8415 \\
\hline \hline
\end{tabular}

Tablo 10'de yer alan Granger nedensellik testi için yapılan Toda-Yamamoto yaklaşımı sonuçlarına göre, eğitim düzeyinden ekonomik büyümeye doğru bir nedensellik tespit edilmiştir. Diğer bir ifadeyle, Türkiye'de 1980-2013 dönemi için eğitim ekonomik büyümenin Granger nedenidir. Ancak ekonomik büyümeden eğitime doğru bir Granger nedensellik bulunamamıştır.

\section{SONUÇ}

Büyüme ve Kalkınma alan yazınında sıkça sorulan sorulardan birisi "gelişmiş ülkeler neden gelişmiştir?" sorusudur. Bu sorunun en temel cevaplarından birisi, gelişmiş ülkelerin eğitime büyük önem vermeleri sonucu nitelikli işgücüne sahip olmalarıdır.

Bu çalışmada, Türkiye'ye ait 1980- 2013 dönemini kapsayan yıllık veriler kullanılarak eğitim ile ekonomik büyüme arasında uzun dönemli olası bir ilişkinin varlığı araştırılmış ve nedensellik analizi yapılmıştır. Bunun için öncelikle durağanlık şartının gerekliliğinden dolayı birim kök testleri uygulanmıştır. ADF ve DF-GLS birim kök test sonuçlarına göre seriler fark durağan özelliği taşımaktadırlar. Diğer bir ifadeyle, değişkenler I(1)'dir. Ardından ARDL ve Johansen yöntemleri uygulanmış ve değişkenlerin uzun dönemde birlikte hareket ettikleri sonucuna varılmıştır. Yani eğitim ve kişi başına düşen gelir değişkenleri arasında eşbütünleşme ilişkisi tespit edilmiştir. ARDL yönteminin uzun dönem modeli çerçevesinde, 1980-2013 yılları arasında eğitim düzeyi kişi başına düşen geliri artırmakta, yani büyüme üzerinde pozitif etki yapmaktadır. Aynı şekilde sermaye ve emek değişkenleri de kişi başına düşen geliri artırmaktadır. ARDL yaklaşımının kısa dönem modelinde ise anlamlı tek değişken sermaye değişkenidir. Dinamik OLS tahmininde de değişkenlerin hem istatistiki hem de iktisadi olarak anlamlı olduğu görülmüştür. Daha sonra, Granger nedensellik testinin uygulanabilmesi için gerekli olan Toda-Yamamoto Testi'ne gidilmiştir. Toda-Yamamoto testi bulgularına göre, eğitim değişkeninden gelir değişkenine doğru bir "Granger nedenselliği'nin" varllğ 1 saptanmıştır. Ayrıca sermaye ve istihdam oranı değişkenlerinin de gelir değişkeninin "Granger nedeni” olduğu tespit edilmiştir. Ancak gelir değişkeninden eğitim değişkeni yönünde bir Granger nedenselliği ise bulunamamıştır.

Sonuç olarak elde edilen ampirik bulgular, 1980-2013 döneminde eğitim düzeyindeki artışın kişi başına düşen geliri artırdığı görülmektedir. Bu bağlamda Türkiye'nin kişi başına düşen gelirinin, gelişmiş ülkeler düzeyine erişebilmesi için en temel yolun eğitimden geçtiği söylenebilir. Bu sebeple, gerek politika yapıcıların bu alanda atılması gereken adımları hızla atması, gerekse de bireylerin her alanda eğitime önem vermeleri sonucu bilgi üretme sürecine hız kazandırabileceğini belirtmek gerekir. Bu sayede de, Türkiye'nin gelişmiş ülkelerin sahip olduğu refah düzeyine ulaşabilmesi için önemli katkılar sağlanabilir. 


\section{KAYNAKÇA}

Afşar, Muharrem (2009). Türkiye'de Eğitim Yatırımları ve Ekonomik Büyüme İlişkisi. Anadolu Üniversitesi Sosyal Bilimler Dergisi, 9(1), 85-98.

Aka, B. F. \& J. C. Dumont (2008). Health, Education and Economic Growth: Testing for Long Run Relationships and Causal Links. Applied Econometrics and International Development, 8(2), 101-113.

Baldacci, E., Clements, B., Gupta, S. \& Cui, Q. (2008). Social Spending, Human Capital, and Growthin Developing Countries. World Development, 36(8), 1317-1341.

Barro, R.J. (1991). Economic Growth in a Cross Section of Countries. The Quarterly Journal of Economics, 106(2), 407-443.

Barro, R. J. \& Lee J. W. (2000). International Data on Educational Attainment Updates and Implications. NBER Working Paper, No: 7911, 1-36.

Barro, R. J. (2001). Education and Economic Growth. OECD Economic Department Working Paper, No: 281, 1-48.

Becker, G. S. (1975). Human Capital: A Theoretical and Emprical Analysis, with Secial Reference to Education. Chicago: University of Chicago Press.

Bozkurt, Hilal (2010). Eğitim, Sağlık ve İktisadi Büyüme Arasındaki İlişkiler: Türkiye İçin Bir Analiz. Bilgi Ekonomisi ve Yönetimi Dergisi, 5(1), 7-27.

Bozkurt, Cuma (2015). Türkiye'de Bilgi-İletişim, Eğitim, Sağlık ve Ekonomik Büyüme İlişkisi: Ampirik Bir Yaklaşım. İşletme ve İktisat Çalışmaları Dergisi, 3(2), 45-56.

Çalışkan, Ş., Karabacak, M. ve Meçik, O. (2013). Türkiye'de Eğitim-Ekonomik Büyüme İlişkisi: 1923-2011 (Kantitatif Bir Yaklaşım). Yönetim Bilimleri Dergisi, 11(21), 29-48.

Çetin, A. ve Yakışık, H. (2014). Eğitim, Sağlık ve Teknoloji Düzeyinin Ekonomik Büyüme Üzerindeki Etkisi: ARDL Sınır Test Yaklaşımı. Sosyo-Ekonomi Dergisi, 21(21), 169-186.

Erdoğan, S. ve Yıldırım, D. Ç. (2009). Türkiye'de Eğitim - İktisadi Büyüme İlişkisi Üzerine Ekonometrik Bir İnceleme. Bilgi Ekonomisi ve Yönetimi Dergisi, 4(2), 11-22.

Eriçok, R. E. ve Yılancı, V. (2013). Eğitim Harcamaları ve Ekonomik Büyüme İlişkisi: Sınır Testi Yaklaşımı. Bilgi Ekonomisi ve Yönetimi Dergisi, 8(1), 87-101.

Feridun, M., Sissoko, Y. (2011). Impact of FDI on Economic Development: A Causality Analysis for Singapore, 1976-2002. International Journal of Economic Sciences and Applied Research. 4(1), 7-17.

Gujarati D. N. \& Porter, D. C. (2012). Temel Ekonometri (Çev. Ü. Şenesen ve G. G. Şenesen). Literatür Yayınları: İstanbul.

Johansen, S. (1988). Statistical Anaylsis of Cointegrating Vectors. Journal of Economic Dynamics and Control. 12, 231-254.

Kalkınma Bakanlı̆̆ı (2016), Ekonomik ve Sosyal Göstergeler, http://www.kalkinma.gov.tr/Pages/EkonomikSosyalGostergeler.aspx (Erişim: 13.11.2016).

Kızılkaya, O. ve Koçak, E. (2014). Kamu Eğitim Harcamaları ve Ekonomik Büyüme İlişkisi: Seçilmiş OECD Ülkeleri Üzerine Bir Panel Veri Analizi. Ekonomi Bilimleri Dergisi, 6(1), 17-32.

Lin, T. C. (2003). Education, technical progress, and economic growth: the case of Taiwan. Economics of Education Review, 22(2), 213-320.

Mankiw, N. G., D. Romer \& D. Weil (1992). A Contribution to the Empirics of Economic Growth. The Quarterly Journal of Economics, 107(2), 407-437.

Mincer, J. (1974). Schooling, Experience and Earnings. New York: Columbia University Press.

Özsoy, Ceyda (2009). Türkiye'de Eğitim ve İktisadi Büyüme Arasındaki İlişkinin VAR Modeli ile Analizi. Bilgi Ekonomisi ve Yönetimi Dergisi, 4(1), 71-83.

Peseran, M. H., Shin, Y. \&Smith, R. J. (2001). Bounds Testing Approaches to the Analysis of Level Relationship. Journal of Applied Econometrics, 16(3), 289-326.

Romer, P. M. (1989). Human Capital and Growth: Theory and Evidence. NBER Working Paper Series, No: 3173, $3(173), 1-51$.

Romer P. M. (1986). Increasing Returns and Long-Run Growth. Journal of Political Economy, 94(5), 1002-1037. 
Schultz T. W. (1961). Investment in Human Capital. American Economic Review, 51, 1-17.

Taban, S. ve Kar, M. (2006). Beşeri Sermaye ve Ekonomik Büyüme: Nedensellik Analizi, 1969-2001. Anadolu Üniversitesi Sosyal Bilimler Dergisi, 6(1), 159-182.

Tarı, R. ve Beşballı, S. G. (2016). Nicel ve Nitel Ölçütleriyle Eğitim-İktisadi Büyüme İlişkisi. Atatürk Üniversitesi İktisadi ve İdari Bilimler Dergisi, 30(2), 375-401.

Terzi, H. ve Yurtkuran, S. (2016). Türkiye'de Eğitim ve İktisadi Büyüme İlişkisi: Sims ve Toda-Yamamoto Nedensellik Analizleri. Eskişehir Osmangazi Üniversitesi İBF Dergisi, 11(2), 7-24.

The World Bank (2016), World Development Indicators, http://databank.worldbank.org/data, (Erişim: 13.11.2016).

Uçan, O. ve Yeşilyurt, H. (2016). Türkiye'de Eğitim Harcamaları ve Büyüme İlişkisi. Niğde Üniversitesi İktisadi ve İdari Bilimler Fakültesi Dergisi, 9(2), 179-185.

Yardımcıoğlu, F., Gürdal, T. ve Altundemir, M. E. (2014). Eğitim ve Ekonomik Büyüme İlişkisi: OECD Ülkelerine İlişkin Panel Eş-bütünleşme Analizi (1980-2008). Eğitim ve Bilim Dergisi, 39(173), 1-12. 